\title{
Research on the Design Specialties Practice Course Teaching Mode Based on "Four Stratums and Four Modules" in the Context of "Innovation and Entrepreneurship Education”
}

\author{
Yan Zhao * \\ Department of Architecture \\ Renai College of Tianjin University \\ Tianjin, China \\ zhaoyanhit@sina.com
}

\author{
Jing Su \\ Department of Art \\ Renai College of Tianjin University \\ Tianjin, China \\ 1470883968@qq.com
}

\begin{abstract}
Now it is the consensus of universities and colleges nationwide to launch teaching reform through positive innovation and entrepreneurship education. Cultivating the consciousness of innovation, entrepreneurship and practical abilities of the college students and encouraging them to start their own business boast great significance for modern China to open up new routes to independent innovation and build the innovative country. The essence of the design specialties is innovation. It is an important effort to carry out "innovation and entre pre ne urship education”, establish the uniform idea of grand design, follow the guidance of innovation and entrepreneurship education, reform the practical teaching system and form the long-term virtuous operating mechanism featuring innovationdriven teaching and activated entrepreneurial abilities, planning the teaching materials on architecture, environment design and animation as a whole, targeting to cultivate practical design talents characterized by high engineering design ability and practical collaborative innovation ability, implementing the pioneering awareness of innovation in the whole process of practical teaching, organizing teaching contents focused on research project, academic competition and engineering project organization and developing the teaching mode based on "four stratums and four modules".
\end{abstract}

Keywords-innovation and entrepreneurship education; design specialties; practice course teaching mode based on "four stratums and four modules"

\section{INTRODUCTION}

Launching innovation and entrepreneurship education in universities and colleges serves as a vital channel to deepen educational reform and cultivate the innovative spirit and practical abilities of college students. China's capability of independent innovation chiefly relies on the development of talents highly capable of independent innovation. Especially, higher education, as a pivotal part of the national innovation system, should energetically promote innovation and entrepreneurship education and cultivate high-caliber talents equipped with the consciousness of innovation, entrepreneurship and practical abilities in a bid to provide vigorous support to build a new type nation. The design

[Fund program]: Research Project on Undergraduate Teaching Quality and Teaching Reform of Universities and Colleges in Tianjin No:171403802E industry is characterized by the facts that art is innovation and thinking can be transformed into productivity, and by strong mutual solubility of different specialties. At present, China's design education vertically grows in different disciplines lacking communication and horizontal exchanges and collaboration, consequently without giving full play to the awareness of innovation and the entrepreneurship of those engaged in designing. Under the uniform idea of grand design, the specialties of architecture, environment design and animation of the Tianjin University Renai College adheres to the thoughts and methods of engineering education, follows the guidance of innovation and entrepreneurship education, reforms the practical teaching system and forms the long-term virtuous operating mechanism featuring innovation-driven teaching and activated entrepreneurial abilities.

\section{CONSTRUCTION OF THE PRACTICAL COURSE TEACHING} SYSTEM BASED ON "FOUR STRATUMS AND FOUR MODULES"

The college plans the teaching materials on architecture, environment design and animation as a whole, targets to cultivate practical design talents characterized by high engineering design ability and practical collaborative innovation ability, implements the pioneering awareness of innovation in the whole process of practical teaching, organizes teaching contents focused on research project, academic competition and engineering project organization and finally establishes the teaching mode based on "four stratums and four modules". It cultivates the practical skills and innovative thinking abilities at the fundamental level, the comprehensive abilities and collaborative design capabilities at the comprehensive level and the collaborative innovation and practical application abilities at the innovation and application level. Besides, open, exploring and project-driven teaching methods have been adopted to guide practical teaching through scientific research and build the fundamental skill module, the special comprehensive module, the practical innovation module and the practical base module from the fundamental, comprehensive, innovative and practical perspectives. 
Since 2013, efforts concerning the specialties of architecture, environment design and animation have been made to further enhance interdisciplinary collaboration, encourage academic exchanges and scientific research, build the practical innovation platform for architecture and design, reasonably and effectively utilize the available teaching and research resources and jointly conduct interdisciplinary research. Two departments implement industry-universityresearch cooperation, effectively integrate the resources and achieve mutual benefits. According to the requirements of the education objectives, teaching plans and course outlines of different specialties as well as the young teaching team building objectives, efforts have been made to exchange teaching methods, jointly carry out scientific research, share university-industry cooperation resources, advance talents building and lay a perfect foundation for the students to better serve the enterprises after graduation. The specialties of architecture, environment design and animation, through several times of investigation, survey and exchanges of teaching methods, jointly research the teaching methods, modular curricula and project collaboration. The Department of Architecture and the Department of Art have successively signed a series of agreements, such as the Agreement on Joint Use of Laboratories, Studios and Specialized Classrooms and On the "Dual-teacher Linkage" Engineering Practice and Innovation Collaboration System, which gradually improves the design modular course teaching system.

\section{THE FUNDAMENTAL SKILL MODULE}

The fundamental level: Focus on the fundamental skill module and enhance the specialized skills of the students, including the practical skills like free-hand sketching, computer-aided design (CAD), and design thinking and methods, in a bid to train the operational abilities of the students and reinforce the basic specialized skills and basic practical skills of the students.

\section{A. Free-hand sketching practice}

Free-hand sketching is most suitable for capturing the accidental inspiration in the course of thinking, which should be further enhanced so as to inspire the mind anytime. For instance, the specialty of environment design sets basic sketching practice, villa landscape design and bathroom interior design for the course of Environmental Design Fundamentals for sophomores. The course emphasizes intensive training of drawing rules, conceptual cognition and expression of basic design and makes special design for villa garden design and bathroom interior design so that the students can have preliminary, systematic cognition of the discipline and the specialty and master the correct thinking and expression methods of design.

\section{B. Computer practice}

The development of computer graphics technology has transformed the mode of building performance. The convenience, efficiency and visual truthfulness of the technique are largely superior to the traditional hand-drawn presentation, enhancing the vital, fundamental role of computer practice in achieving better practical teaching effects at the fundamental level. For instance, the specialties of architecture and environment design include computer graphics in the teaching for sophomores and meanwhile arrange for architectural design teaching plan according to the theoretical course in corresponding terms, changing from substantial, single, hand-by-hand counseling for modification to the combination of small and large classroom, partial "processing" of individual problems and common problems, applying computer technology, recording software-based classroom teaching in video and sending to the students for after-class review to boost the teaching efficiency.

\section{Design thinking}

The design specialties are featured by the combination of skill and art. To some extent, "creation and design" can not be distinctively separated. For this reason, it is critical to strengthen design thinking training at the fundamental level to cultivate the students' consciousness of innovation. For instance, the freshmen and sophomores majoring in animation should systematically learn the animation design basics, for instance, art basics-pencil sketch, colors and compositions etc and animation basics_-law of motion, shooting script, character design and scene design etc, adding design thinking training on the basis of reinforcing the students' basic skills. The juniors and seniors who will practice in studios should receive special cultivation and training of design thinking in two-dimensional direction, three-dimensional direction and stop motion, for instance, the animation practice module in different directions guarantees the connectivity and comprehensive application of knowledge.

\section{COMPREHENSIVE TRAINING PRACTICE MODULE}

At the comprehensive level: Focus on comprehensive training, including comprehensive curricula, comprehensive specialties and interdisciplinary comprehensive practice module to cultivate the abilities of the students to comprehensively apply their knowledge to solve practical problems.

\section{A. Comprehensive curricular practice}

As to the design course series, efforts should be made to combine the teaching contents with the characteristics of the students, reform the traditional teaching contents and explore a set of new teaching methods. In the practical teaching of the design course series of each grade, the reformed teaching mode featuring "deep optimization and distinct gradation" achieves favorable effects.

\section{B. Special comprehensive practice}

Endeavors for students of senior classes should be made to focus on practical teaching, make use of the platforms and mechanisms of school training base and studios and encourage the students to master the comprehensive specialized knowledge and skills they've learnt to complete the practical engineering projects under the guidance of the supervisors on and off campus. For instance, specific projects have served in the teaching for the specialty of animation. In the recent years, the college has completed actual projects of more than 30 episodes jointly with Renyong Movies \& Television Cartoons Making \& Broadcasting Co., Ltd, Jiayutong Movies \& Television Cartoons Making \& Broadcasting Co., Ltd and Feicui Animation Company etc. Among them, the 26-episode 2D animation Lost in the City has been broadcasted by 
Liaoning Television. The studio has created 22 threedimensional original animation works, more than 10 twodimensional animation works and more than 10 stop-motion animation works.

\section{Interdisciplinary comprehensive practice}

Several interdisciplinary students conduct teamwork, give full play to the advantages of their own specialties and collaboratively, innovatively complete some comprehensive practice projects. For instance, the students majoring in architecture and environment design, as a team, completed the Deep University-Enterprise Collaboration for EducationExpanded Application of Lighting Design, a municipal-level training project for innovation of college students in Tianjin and won totaling seven outstanding awards including a gold award, a silver award, a bronze award and four excellence awards in the Asian Design Award. Additionally, they won three awards including a bronze award and an excellence award in the "New Designer" Cup National Interior Design Contest (Fig.1).
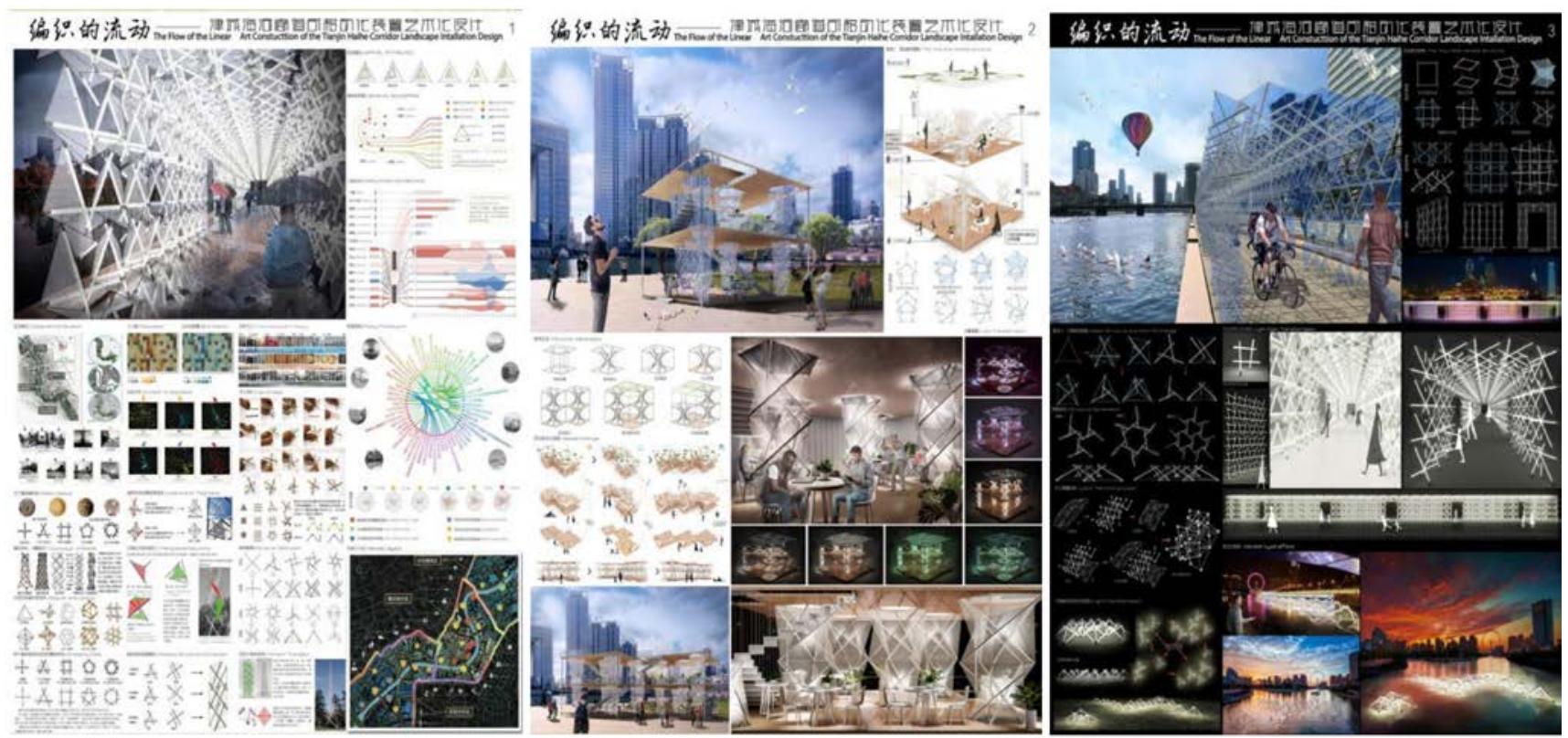

The 15th 2017 Asian Design Award Competition Program Gold Award

Fig. 1. Award-winning works of university students for innovative undertaking projects

\section{ARCHITECTURE AND ART PRACTICE AND INNOVATION MODULE}

At the innovation level: Focus on the architecture and art practice innovation module, emphasize the cultivation of the students' entrepreneurial ability. Make use of the specialized knowledge and skills to carry out practical training centering on teaching through competition, innovation and entrepreneurial practice and studio project practice to further improve the students' innovative ability in practice, ability to start their own business and employability.

\section{A. Competition teaching practice}

For four years, the students majoring in architecture, environment design and animation have competed on the platforms for their specialized skills and achieved breakthroughs and excellent academic performance in contests on their disciplines and specialties at the international, national and municipal levels: The teachers and students have accumulatively won 279 awards, including 199 awards (including 22 gold awards, 31 silver awards and 37 bronze awards) for the students, 69 Excellent Guide Teacher Awards and 11 Organization Unit Awards (TABLE I).

TABLE I. AWARDS FOR ST UDENT S, TEACHERS AND COLLEGES (2013-2017)

\begin{tabular}{|c|c|c|c|c|}
\hline Level & Award name & Students & Teachers & Colleges \\
\hline $\begin{array}{l}\text { International } \\
\text { competitions }\end{array}$ & $\begin{array}{l}\text { Asian Design Award } \\
\text { Busan International Architecture Competition } \\
\text { International Landscape Planning \& Design Competition } \\
\text { UIA International Student Competition in Architecture Design }\end{array}$ & $\begin{array}{c}\text { Gold Award: } 4 \\
\text { Silver Award: } 7 \\
\text { Bronze Award: } 14 \\
\text { Excellence Award: } \\
36\end{array}$ & $\begin{array}{c}\text { Excellent Guide Teacher } \\
\text { Award: } 21\end{array}$ & $\begin{array}{l}\text { Organization Unit } \\
\text { Award: } 5\end{array}$ \\
\hline
\end{tabular}


Cont. to TABLE I

\begin{tabular}{|c|c|c|c|c|}
\hline $\begin{array}{c}\text { National } \\
\text { competitions }\end{array}$ & $\begin{array}{c}\text { National Undergraduates Architectural Design Scheme } \\
\text { Competition } \\
\text { National Undergraduates Interior Design Competition } \\
\text { Environment Design Academic Year Award } \\
\text { Chinese Landscape Architecture Graduate Works Exhibition } \\
\text { National College Competition for Fine Art Works for } \\
\text { Architecture and Environment Design } \\
\text { National Art Education Appraisal \& Achievement Exhibition }\end{array}$ & $\begin{array}{l}\text { Gold Award: } 11 \\
\text { Silver Award: } 11 \\
\text { Bronze Award: } 12 \\
\text { Excellence } \\
\text { Award: }>40\end{array}$ & $\begin{array}{c}\text { Excellent Guide Teacher } \\
\text { Award: } 18 \\
\text { Gold Award for Teachers' } \\
\text { Works: } 2 \\
\text { Silver Award for Teachers, } \\
\text { Works: } 4\end{array}$ & $\begin{array}{l}\text { Organization Unit } \\
\text { Award: } 5\end{array}$ \\
\hline $\begin{array}{l}\text { Provincial } \\
\text { competitions }\end{array}$ & $\begin{array}{c}\text { Tianjin PAK Electrical Design Competition } \\
\text { Tianjin Youth Art Festival \& Animation Contest } \\
\text { Tianjin Undergraduate Original Animation Contest } \\
\text { Tianjin Youth New Media Creative Activities Microanimation } \\
\text { Competition }\end{array}$ & $\begin{array}{l}\text { Gold Award: } 1 \\
\text { Silver Award: } 9 \\
\text { Bronze Award: } 8 \\
\text { Excellence } \\
\text { Award: }>30\end{array}$ & $\begin{array}{c}\text { Excellent Guide Teacher } \\
\text { Award: } 22 \\
\text { Gold Award for Teachers' } \\
\text { Works: } 1 \\
\text { Silver Award for Teachers' } \\
\text { Works: } 1\end{array}$ & $\begin{array}{l}\text { Organization Unit } \\
\text { Award: } 1\end{array}$ \\
\hline \multicolumn{2}{|r|}{ Item statistics } & 199 & 69 & 11 \\
\hline & Total & \multicolumn{3}{|c|}{279} \\
\hline
\end{tabular}

\section{B. Innovation and entrepreneurial practice}

Efforts have been made to set up incubation working team for undergraduate entrepreneurship, plan the teaching resources including teaching teams, scientific research and engineering practice as a whole, introduce innovation and entrepreneurial practice projects into class and accomplish outstanding achievements. For instance, innovative training subjects concerning architecture and environment design were brought forward pertinently according to the research domains of the guide teachers and the development of the industry. On this basis, the students deepened, expanded and incubated the training and won the approval for three national and two municipal innovation training projects. As to the inadequate cultivation of the students' innovative ability, the specialty of animation closely combined the first classroom with the extracurricular classroom, helped the students win the teachers' approval for projects and create their original works and cultivated abilities for original innovation. Three municipal innovation training projects have been approved.

\section{Studio project practice}

To better achieve the teaching objective of cultivation applied talents, diversify the talent cultivation modes and adapt to the specialty development tendency, the design specialties, based on the teaching resources accumulated for years and the university-enterprise cooperation platforms, energetically set up studios and led practical teaching. For instance, the juniors and seniors majoring in animation broke the boundaries of different classes of different grades and jointly participated in creation in the studios, with their enthusiasm for creation highly motivated. During their college life, they have jointly published five cartoon books and many of them have published their works in magazines.

\section{PRActice Base MOdULE}

At the application level: Focus on the practice base module; tightly adhere to the objective of cultivating applied talents of design specialties; reinforce practice and realize practical teaching for $40 \%$. The practice base module: Positively expand practice base for design specialties, establish the university-enterprise cooperation mechanism and extensively optimize the practice base module on and off campus. For instance, for the practice of ancient architecture mapping for architecture majors, the teachers, during four academic years, led the students to successively participate in numerous large scale projects, including the surveying and mapping of the ancestral hall group in Wuxi, Yuan Tomb (Yuan Shih-kai, the Hall of Mental Cultivation in the Forbidden City, the surveying, mapping and modeling analysis of the Chongling Mausoleum of the Qing Dynasty in Xiling and the Dingling Mausoleum and the Hui Tomb of the Qing Dynasty in Dongling and the surveying, mapping and research of stone historical relics in the North Sea. The practice expanded their specialized theoretical knowledge and skills and further enhanced their practical application ability and professional identity. The specialty of animation has set up several practice bases and all the students of this specialty have the chance of practice.

\section{CONCLUSION}

The uniform idea of grand design is a new concept of the discipline of design proposed in recent years, continuously presenting a trend of interconnection and vertical development. Innovation and entrepreneurship education is the practical education of hierarchical innovative thinking cultivation and entrepreneurial ability training. The present research integrates the uniform idea of grand design and the innovation and entrepreneurship education into the cultivation objectives for applied design talents featuring engineering design execution abilities and collaborative innovative practical abilities, carries forward the strategies of engineering education reform and builds the practical course teaching mode based on "four stratums and four modules”. The efforts to advance teaching through projects, boost the design ability through competition and break through professional barriers can realize the expansion and multi-directional integration of teaching equipment, projects and team resources, industry-universityresearch cooperation and diversified cultivation. It can also form a positive operating mechanism of the "panoramic industrial chain" featuring long-acting, interdisciplinary, collaborative, innovative integration of all grades. Since the implementation of the project four years ago, the students have significantly benefited from it, demonstrating its remarkable 
radiation effects: The quality of cultivated students of design specialties of four grades totaling more than 1,000 has been substantially enhanced; the teachers and students have grossly won 279 awards in high-level professional design contests, with some of the awards surpassing those of domestically key universities and colleges. The comprehensive quality of the graduates has been highly appraised by the employers. This year's graduates are favored by the employers. Some of the graduates have taken charge of some national key bid projects.

\section{REFERENCES}

[1] LI Huan-ao. The R eform and Implementation of Talent Training Mode in Studio Project-based System-A Case Study of the Art Design Major in Chengyi College of Jimei University [J]. Journal of Jimei University, 2017, pp:82-88(In Chinese)
[2] Liu Wei. Thoughts of Construction on Personnel Cultivating System of Innovation entrepreneurship Education in Colleges and Universtities [J].Education Science, 2011, Vol27, No5, pp:64-67(In Chinese)

[3] Wang Zhanren. The Overall Plan of Reforming Educational Ideas on HEI Innovation Entrepreneurship Education in China[J]. China Higher Education Research, 2015, No5, pp:75-78(In Chinese)

[4] LIU Chang-hong, LI Xiao-hui, LI Gang, YUE Qing-rong, R EN Yonggong. Practice and Exploration of the Undergraduate Innovation and Entrepreneurship Training Program[J].Research and Exploration in Laboratory, 2014, Vol33, No5, pp:163-166(In Chinese)

[5] Wan Liyong, Kang Cuiping. Internet plus Maker Education: Construction of the New Ecology for Innovation and Entrepreneurship Education in Universities[J]. Research in Education Development, 2016, No7, pp:59-65(In Chinese)

[6] Li Fengqing, Han Xiaoling. The Construction and Demonstration of Blending Teaching Quality Evaluation System[J]. Instruction and Teacher Professional Development, 2017, No11, pp:108-113(In Chinese) 